\title{
Tulane
}

Tulane Economics Working Paper Series

\section{Enforcement, Socio-Economic Diversity, and Tax Filing Compliance in the United States}

\author{
James Alm \\ Department of Economics \\ Tulane University \\ jalm@tulane.edu
}

\author{
Jeremy Clark \\ Department of Economics and Finance \\ University of Canterbury \\ jeremy.clark@canterbury.ac.nz
}

\author{
Kara Leibel \\ Office of Research \\ Internal Revenue Service \\ kara.e.leibel@irs.gov
}

Working Paper 1514

April 2015

\begin{abstract}
In this paper we examine the determinants of tax filing compliance in the United States. We use county-level data on non-filing rates for the tax year 2000, obtained directly from the Internal Revenue Service. We include explanatory variables identified in the "rational compliance" framework, including an enforcement index against identified non-filers, the audit rate of filers, and the average penalty rate for both filers and non-filers. We also examine the role of socio-economic diversity on tax compliance, testing whether within-county heterogeneity in household income, language, race, and religion can help explain variation in non-filing rates. We find that non-filing is increasing with heterogeneity by race, though not by income or language, and that non-filing is decreasing with heterogeneity by religious membership. As for enforcement variables, we find that non-filing rates tend to fall with the enforcement index. Other variables have somewhat mixed results.
\end{abstract}

Keywords: tax evasion, social capital, diversity JEL codes: H2, H26, H31 


\title{
ENFORCEMENT, SOCIO-ECONOMIC DIVERSITY, AND TAX FILING COMPLIANCE IN THE UNITED STATES
}

\author{
James Almª ${ }^{\mathrm{a}}$ Jeremy Clark ${ }^{\mathrm{b}}$, and Kara Leibel ${ }^{\mathrm{c}}$
}

\begin{abstract}
In this paper we examine the determinants of tax filing compliance in the United States. We use county-level data on non-filing rates for the tax year 2000, obtained directly from the Internal Revenue Service. We include explanatory variables identified in the "rational compliance" framework, including an enforcement index against identified non-filers, the audit rate of filers, and the average penalty rate for both filers and non-filers. We also examine the role of socio-economic diversity on tax compliance, testing whether within-county heterogeneity in household income, language, race, and religion can help explain variation in non-filing rates. We find that non-filing is increasing with heterogeneity by race, though not by income or language, and that non-filing is decreasing with heterogeneity by religious membership. As for enforcement variables, we find that non-filing rates tend to fall with the enforcement index. Other variables have somewhat mixed results.
\end{abstract}

\section{JEL Classification: H24, H26, H31}

\footnotetext{
${ }^{a}$ Department of Economics, Tulane University, 6823 St. Charles Avenue, 208 Tilton Hall, New Orleans, LA, 70118. Phone: +1 504862 8344. Email: jalm@ tulane.edu.

${ }^{\mathrm{b}}$ Department of Economics and Finance, University of Canterbury, Private Bag 4800, Christchurch, New Zealand. Phone: 011643364 2308. Email: jeremy.clark@ canterbury.ac.nz.

${ }^{\mathrm{c}}$ Office of Research, Internal Revenue Service, 1111 Constitution Avenue, N.W., $3{ }^{\text {rd }}$ Floor/017, Washington, DC 20224. Email: kara.e.leibel@irs.gov.
}

The research reported here was partially funded by the IRS (TIRNO-10-P-00679). The views expressed are those of the authors, and do not reflect the opinions of the Internal Revenue Service (IRS) or of any researchers working within the IRS. We thank Kim Bloomquist, Ed Emblom, Ana Ferrer, David Gray, Arvind Magesan, Rosemary Marcuss, Andrea Menclova, Alan Plumley, Bob Reed, Stephen Ross, Joel Slemrod, Jean-Francois Wen, and Elizabeth Wilman for their comments, as well as seminar participants at Calgary, Columbia, Connecticut, Guelph, Massachusetts-Amherst, and Syracuse, and session participants at the 2011 Tax Research Network, 2012 Canadian Economics Association Meetings, and 2012 and 2013 National Tax Association Meetings. We also thank the Editor and three anonymous referees for many insightful suggestions. 


\section{INTRODUCTION}

Non-compliance with the tax laws is a perennial problem in all tax systems, including the United States. The U.S. Internal Revenue Service (IRS) estimates that in 2006 the gross individual income "tax gap", or the amount of the true income tax liability that is not paid by the filing deadline, was $\$ 296$ billion (IRS 2012). Much of this is due to the under-reporting of income on filed tax returns, but as much as 8 percent (or $\$ 25$ billion) is accounted for by nonfiling of returns. Analyzing any type of tax evasion faces obvious difficulties of measurement. ${ }^{1}$ Analyzing tax evasion for individuals who choose not to file a tax return is especially challenging. These individuals are not "in the system", not having filed a legally required tax return in the recent past or perhaps ever, so that information on these individuals is seldom available. Indeed, Cowell (1990) and Erard and Ho (2001) have referred to those who do not file as "ghosts". In this paper we use county-level data on non-filing rates for the tax year 2000, obtained directly from the Internal Revenue Service, to examine the factors that affect the nonfiling decisions of individuals.

The standard analysis of tax evasion suggests several obvious factors in the non-filing decision, such as those that emerge from the standard "rational compliance" framework of Allingham and Sandmo (1972), including enforcement measures like audits and penalties. However, although there is no question that deterrence is an important determinant of compliance, there is now much evidence that individuals are motivated by additional factors beyond those that capture the purely financial benefits and costs of their decisions (Andreoni, Erard, and Feinstein 1998; Kirchler et al. 2010). These other factors seem likely to play a role. ${ }^{2}$

In particular, measures of socio-economic diversity, such as heterogeneity in household income, language, race, or religion, seem likely to affect an individual's willingness to pay 
legally due taxes. These factors may well capture notions of "social norms" (Elster 1989). They may also reflect the impact of "social capital" on the non-filing decision. Social capital is defined by Putnam (2007) as people's beliefs and actions that contribute to “... social networks and the associated norms of reciprocity and trustworthiness." A growing body of literature has shown that social capital is negatively associated with, and possibly caused by, greater socio-economic diversity, with significant impacts on such outcomes as government spending (Poterba 1997; Alesina, Baqir, and Easterly 1999) or census form return rates (Vigdor 2004). ${ }^{3}$

Income tax compliance and its relationship to socio-economic diversity have only been examined in a limited fashion. La Porta, Lopez-de-Silanes, Shleifer, and Vishny (1999) and Alesina, Devleeschauwer, Easterly, Kurlat, and Wacziarg (2003) both use a national index of tax compliance constructed from survey data for the 1996 Global Competitiveness Report, and each study finds a negative correlation between ethnic heterogeneity and compliance. $\mathrm{Li}$ (2010) uses World Values Survey data that ask respondents whether cheating on taxes is justifiable, and similarly finds more sympathy for non-compliance in countries with greater ethnic heterogeneity. However, these studies rely on survey data rather than actual compliance behavior, so it is unclear whether these attitudes carry over into individuals' actions. This distinction between attitudes and actions is critical. To our knowledge, there are no studies that have examined the effects of social heterogeneity on actual tax compliance based on individual behavior.

Our paper examines the determinants of non-filing behavior, including standard enforcement measures as well as measures of socio-economic diversity. We estimate the covariation of individual income tax filing compliance rates and its many determinants, using county-level data on actual individual filing rates for the United States for the year 2000. Such field data on actual compliance behavior are notoriously difficult to obtain; even when some 
compliance data have been available, they have typically been for reporting non-compliance, focusing on individuals who file tax returns but do not declare all taxable income (Clotfelter 1983; Dubin, Graetz, and Wilde 1990; Gentry and Kahn 2009). There are few empirical (or even theoretical) studies on the determinants of the logically prior form of filing non-compliance, or whether individuals file tax returns when required by law to do so. ${ }^{4}$

Our measure of tax filing compliance is constructed from IRS data on non-filers, or those whom the IRS identifies as having stopped filing without clear cause or for whom filing should be expected based on third-party income reports. ${ }^{5}$ We construct standard enforcement variables, and we control for potential endogeneity of these enforcement variables in our estimations. Further, we construct measures capturing diversity across income, race, language, and religion, again at county level.

We find that non-filing rates tend to fall with the enforcement index. We also find that non-filing is increasing with heterogeneity by race, though not by income or language, and that non-filing is also decreasing with heterogeneity by religious membership. Other variables have somewhat mixed results. For example, non-filing rates rise with the share of county income from self-employment or public assistance, the share foreign born, the share in poverty, the share aged 45-64, and the share living in owner-occupied housing. Non-filing rates fall with the share of a county's population that is married, residentially stable, and working.

\section{A Theoretical Framework of Tax Filing Compliance and Social Heterogeneity}

We are interested in the determinants of non-filing behavior. However, the decision on whether or not to file a tax return depends closely on the decision of how much income to report on a tax return that is filed, since the return to the latter reporting decision affects the payoff to 
the former non-filing decision. We start with the reporting decision in the standard economics-ofcrime model of Allingham and Sandmo (1972), and then extend this model to tax filing compliance using the framework developed by Erard and Ho (2001), Alm, Cherry, Jones, and McKee (2010), and Kleven et al. (2011). ${ }^{6}$

Starting with the reporting decision, an individual who decides to file a tax return and report income $R$ has expected utility shown by equation (1):

Reporting: $E U=(I-p) U(I-t R-C)+p U(I-t R-(I+f) t(I-R)-C)$.

Here $U($ ) is the utility function, $I$ is the individual's "true" income, $p$ is the probability that a tax return is selected for audit (termed the "audit probability"), $t$ is the tax rate on reported income, $f$ is the penalty rate on undeclared taxes, and $C$ is the burden of preparing and filing a tax return. The individual choose the optimal level of reported income $R *$ to maximize equation (1).

To incorporate the filing decision, we assume that the individual compares the expected utility from filing with optimal income reporting to the expected utility from non-filing. An individual who chooses not to file a tax return has expected utility shown in equation (2):

Filing: $E U=\left(1-p^{\prime}\right) U(I)+p^{\prime} U\left(I-\left(1+f^{\prime}\right) t I\right)$.

Here $p^{\prime}$ is the probability that an individual with income $I$ who has not filed a return is detected and fined by the tax agency (termed the "enforcement probability"), and $f$ " is the penalty imposed on these non-filers. Note that $p$ ' is likely to be different than $p$ because the risk of enforcement for non-filing is different than the risk of audit for a return that is "in the system", that $f$ ' is likely to exceed $f$, and that an individual who does not file a return escapes the filing $\operatorname{cost} C$. To decide whether or not to file a tax return, the individual will thus compare the expected utility from filing and reporting the optimal $R^{*}$ in equation (1) with the expected utility from not filing in equation (2) and choose the greater. 
This framework can easily be expanded to incorporate other relevant considerations. Here we focus on three, largely to help in the empirical specifications that follow.

The first is the possibility that the probability of detection for filers depends upon the amount of reported income, or $p(R)$, with $d p(R) / d R<0$. This assumption follows from standard audit procedures in tax administrations around the world. Its empirical implication is that audit rates may be endogenous. ${ }^{7}$

The second and related consideration is third-party reporting. A standard feature of individual income tax systems is that a third-party (e.g., the individual's employer) reports the relevant part of an individual's taxable income to the tax authority (and often also withholds income taxes on this reported taxable income). This information increases significantly the chances that an individual who either does not file a return at all or who underreports income on a filed return will be detected. To address this, we partition true income $I$ between what is subject to third-party reporting $\left(I_{T P R}\right)$ and what must be self-reported $\left(I_{S R}\right)$. The audit rate for returns $p$ is now assumed to be a function both of reported income $R$ and of income subject to third-party reporting $I_{T P R}$, or $p\left(R, I_{T P R}\right)$. The presence of third-party information also affects the probability of enforcement against non-filers on income subject to third-party reporting, or $p^{\prime}\left(I_{T P R}\right)$. The empirical implication of this assumption is that non-filing rates may depend on the types of income received by the individual.

A third consideration is the role that factors beyond enforcement may play in an individual's reporting and filing decisions. As noted earlier, there is abundant evidence that individuals are motivated not simply by self-interest but also by group notions like social norms, social capital, social customs, social networks, fairness, trust, reciprocity, intrinsic motivation, or tax morale, as well as by individual notions of guilt, shame, morality, or altruism. Many of these 
group notions suggest that the nature of one's social interactions with others may affect one's own compliance decision. In particular, it has been suggested that increased social heterogeneity may lower people's desire to contribute to public goods and transfers that benefit others perceived to be less like themselves (Vigdor 2004; Luttmer 2001), or may reduce their guilt from not doing so. It may also increase disagreement about the types of public goods that taxes should fund and therefore the amount of taxes that should be raised (Alesina, Baqir and Easterly 1999). ${ }^{8}$

To incorporate this consideration, we introduce a non-pecuniary (or psychic) cost $\gamma(H)$ that is incurred by the individual when taxes are not filed or filed but not fully paid $\left(R^{*}<I\right)$. However, these psychic costs may fall if individuals believe that public services funded by their taxes are benefiting people who differ from themselves. Thus, as various dimensions of diversity increase, any dis-utility associated with not filing tax returns and paying taxes should decrease. As a result, we assume that this psychic cost decreases with the amount of social heterogeneity. ${ }^{9}$ The empirical implication would be that measures of heterogeneity may affect non-filing rates.

Putting these three considerations together, the reporting and filing decisions become: Reporting: $E U=\left(1-p\left(R^{*}, I_{T P R}\right)\right) U\left(I-t R^{*}-C-\gamma(H)\right)+p\left(R^{*}, I_{T P R}\right) U\left(I-t R^{*}-(I+f) t\left(I-R^{*}\right)-C-\gamma(H)\right)(1)^{\prime}$ Filing: $E U=\left(1-p^{\prime}\left(I_{T P R}\right)\right) U(I-\gamma(H))+p^{\prime}\left(I_{T P R}\right) U\left(I-\left(1+f^{\prime}\right) t I-\gamma(H)\right)$.

As before, the individual chooses whether or not to file a tax return by comparing the value of expected utility from (2)' with that from (1)' with $R^{*}$ optimized. In the face of these many elements, the impacts on the individual's compliance decisions of variables like the tax rate and income reflect complicated interactions of income and substitution effects, and unambiguous comparative statics results become elusive. For the enforcement variables (e.g., the probabilities of audit of filers or enforcement against non-filers and the penalty rates), the comparative statics results are more straightforward, indicating that an increase in, say, the enforcement probability 
against non-filing decreases the payoff to non-filing. The impact of heterogeneity is not clear-cut because it changes the psychic cost of cheating in both the reporting and filing decisions.

Regardless, however, it is straightforward to demonstrate that the likelihood of non-filing will depend upon an array of fiscal factors, like the probabilities of audit for filers and of enforcement for non-filers (where these probabilities may be endogenous), the penalty rates for filers and for non-filers, the tax rate, and income. The composition of income between third-party verified and unverified sources will affect the probabilities of audit for filers and of enforcement for non-filers. Non-filing will also depend upon unobserved preferences or costs associated with filing that may be proxied by socio-demographic variables (e.g., marital status, education, first language, race, or age). Finally, socio-economic heterogeneity may affect the non-filing decision, as captured by dispersion measures of salient characteristics that people notice in those around them, such as income, first language, race, or religion. The next section presents our empirical framework for estimating these various impacts.

\section{Data Sources, VARiable Construction, and Estimation STRategY Data Sources and Variable Construction}

We have assembled data on IRS-identified non-filing rates for counties in the United States for 2000, as well as on IRS-sourced measures of "rational compliance" variables such as audit rates of filed returns, the likelihood of imposed penalties on identified non-filed returns, and effective penalty rates on delinquent filers and on filed returns containing misreported income or other errors. ${ }^{10}$ To these we have added census and other non-IRS variables used to measure social heterogeneity, income levels, source of income as it affects third-party reporting, and demographic characteristics that signal potential pecuniary benefits from filing (e.g. the 
Earned Income Tax Credit (EITC)) or that proxy for unobserved preferences regarding compliance. Summary statistics are provided in Table 1. Here we discuss the key variables.

Our approach for creating a non-filing rate is to divide the number of non-filers identified by the IRS by an estimate of the population with a filing requirement in a given year and county. The estimate of the population with a filing requirement is calculated as the sum of the number of non-filers, the number of filed returns by single and married-filing-separately taxpayers, and two times the number of filed returns by married-filing-jointly taxpayers. The identified nonfilers are discovered by the IRS through a largely automated procedure that matches current filing data with prior year filing status and number of dependents to estimate appropriate deduction and exemption amounts. Individuals are considered non-filers by the IRS if their thirdparty-reported income totals more than the filing threshold for single filers (the lowest possible threshold) and no return is filed by the filing deadline. Our main measure of non-filing is restricted to those likely to owe some positive revenue amount according to IRS estimates and calculations; this measure further excludes late-filers and the deceased. There are limitations to the automated procedure we use for identifying revenue owed, as contrasted to the refinements subsequently used by the IRS to identify non-filers for enforcement action, though the aggregate non-filer tax gap estimated from the automated procedure ( $\$ 30-\$ 35$ billion) is not that far off that estimated by the IRS with subsequent corrections and adjustments ( $\$ 25$ billion). ${ }^{11}$

With these limitations in mind, we test the robustness of our results using alternative definitions of non-filing. For this purpose, we create both a broader and a narrower measure of non-filers. The broader measure extends our definition to include late-filers and those estimated to not owe any revenue; it is largely the same as the full set of non-filers identified by the IRS in an initial automated procedure, differing only in that it excludes deceased persons. Thus, the 
broader measure attempts to capture all (identifiable) individuals who did not meet their filing requirement in a timely manner, regardless of whether they filed late or how much revenue they owed. However, it may include some individuals who may not have needed to file and are therefore "innocent" non-filers. Our narrower measure restricts the main measure further to those believed to owe more than $\$ 500$ in revenue. This latter measure has the benefit that it is more likely to exclude the ex-post "innocent" and include the ex-post guilty, though the limitations of our filtering exercise mean that even here we cannot be completely certain that all the innocent are excluded. The results for these alternative measures are discussed later.

Our "rational compliance" measures are constructed as follows. To capture $p$, we follow standard practice and use an "audit rate", defined at the county level as the number of individual income tax audits initiated in a given year divided by the number of returns filed in that year. We assume that this audit rate affects the filing decision in the subsequent calendar year.

Identified non-filers face a different enforcement process than filers and are not technically audited, so we cannot use an audit rate to reflect the likelihood of enforcement relevant to the filing decision, or $p^{\prime} \cdot{ }^{12}$ Plumley (1996) and GAO (2003) capture enforcement against non-filers by using the number of notices sent to non-filers. To be consistent with our theoretical model, we consider "enforcement" to occur when the IRS assesses unpaid taxes, penalties, and interest against the non-filer. This is appropriate because it is only when the assessment is made that the individual switches from the (1-p') state to the $p$ ' state and has to pay additional amounts. Our "enforcement index" is then defined for a given year as the number of identified non-filers (technically "delinquent returns") who have an initial financial assessment made against their account in the fiscal year divided by the number of individuals identified as 
non-filers in that year. We assume that the enforcement index will influence the filing decision made in the subsequent year.

The rational compliance model also indicates that the severity of the punishment, captured by proportional fine rates $f$ and $f^{\prime}$, should influence reporting and filing decisions. For non-filers, the IRS imposes a failure-to-file penalty that is typically 5 percent of unpaid taxes for each month the return is late, up to a maximum of 25 percent. Interest may also be charged on any unpaid tax from the due date of the return, at the federal short-term rate plus 3 percent, compounded daily. Despite the stability of the penalty formula over time and counties, there may still be variation in effective penalty rates due to abatements, time to detection (and thus interest charged), and similar considerations. We thus define a penalty rate for non-filers $f$ ' by calculating the ratio of net penalties plus interest divided by net tax assessed for each delinquent return whose most recent assessment or abatement was in the given fiscal year; we average these across individuals to get a county-level measure. We construct a penalty rate for filers $f$ in a similar way. Both the non-filer and filer penalty rates are assumed to affect the filing decisions in the subsequent year.

Figure 1 provides scatter plots of the non-filing rate against the average penalty rate for pursued non-filers, the enforcement index against identified non-filers, the average penalty rate for detected non-filers, and the audit rate of filers. As expected, the non-filing rate is negatively correlated with the enforcement index, and is strongly positively correlated with the audit rate of filers. There is little correlation with penalty rates.

For our measures of social heterogeneity, we create separate variables for language, race, religion, and income. For the qualitative language, race, and religion variables, we follow the social capital literature in using "fragmentation" measures, defined as $F=1-\sum_{i=1}^{n} s_{i}^{2}$. A 
fragmentation index $F$ begins by dividing a population into $n$ categories, and then each category's share of the population is squared, summed, and subtracted from 1 . The index $F$ is bounded between zero (complete homogeneity) and 1 (complete heterogeneity), with the exact upper bound increasing in $n .^{13}$

For language spoken at home, we define $F_{\text {Language }}$ over 3 categories: English, Spanish, and Other. We used only three language categories because no single third language came remotely close in frequency of use in the United States. For race, we define $F_{\text {Race }}$ using the 7 categories used in the 2000 census: White Non-Hispanic, White Hispanic, Black Non-Hispanic, Black Hispanic, American Indian/Alaskan Native, Asian, and Hawaiian/Pacific Islander. For religion, we define $F_{\text {Religion }}$ using the 6 aggregate categories of enumerated adherents at churches and other religious organizations available from the Association of Religion Data Archives (ARDA): Mainline Protestant, Evangelical Protestant, Roman Catholic, Orthodox, Other Religions, and Unclaimed. ${ }^{14}$ Recognizing that our results might be affected by how coarsely race, language, or religion categories are defined, we also tried alternative coarser groupings for race and religion. ${ }^{15}$

Finally, for quantitative measures of income, we measure the dispersion of household income $F_{\text {Income }}$, using the Gini coefficient as provided by the Census. Like the fragmentation index, the Gini is bounded between 0 and 1 and increases in heterogeneity.

Figure 2 provides scatter plots of county non-filing rates against the Gini coefficient for household income inequality, and fragmentation indexes for language, race, and religion. Moderate positive correlations appear between non-filing and both income and language heterogeneity, at 0.42 and 0.30 , respectively. A stronger positive correlation appears between non-filing and racial fragmentation, at 0.71 . Finally, a moderate negative correlation appears between non-filing and religious-adherents fragmentation, at -0.24 . 
To give a spatial feel for non-filing rates and various measures of social-economic diversity in the United States, we provide county-level maps showing these variables for the year 2000. Figure 3 illustrates our main variable of interest: the non-filing rate. Although the rate of detected non-filing is fairly low across the board, it is highest in the South-East, South-West, and West Coast, and lowest in the North and North-East. We see that the non-filing rate appears spatially correlated across adjacent counties, which we address using state dummy variables.

Figure 4 demonstrates how each of the four measures of social heterogeneity vary by county across the United States. There are quite distinct patterns for each measure. The race/ethnicity fragmentation index shows perhaps the starkest variation, with one large swath across the North appearing to be in the lowest band of heterogeneity and another large swath across the South showing the greatest degree of heterogeneity. Income inequality seems to vary the least, with much of the country populating the middle ranges of the Gini coefficient, although this may reflect differences in the construction of variables between the Gini and the three fragmentation indexes. There appear to be only limited correlations between these measures, which we confirm in our empirical work.

\section{Model Specification}

The simple correlations suggest that tax filing compliance may be related to enforcement variables and to social-economic diversity. To further investigate these relationships, we conduct regression analysis in which we consider the determinants of tax non-filing more broadly while controlling for other factors that may affect the raw correlation results. We estimate cross-section regressions for the year 2000, a year in which almost all variables are available at the county level from population counts. 
Our dependent variable is the county non-filing rate in the $0-1$ interval, so we use a logit transformation to map the rates to the real line (Baum 2008). Aside from the IRS-sourced enforcement variables, other control variables are taken at county level from the United States Census of 2000, the Association of Religion Data Archives (ARDA), and the Area Resource File. To proxy for eligibility for the EITC, we include the share of the population in the civilian labor force, the unemployment rate, average household size, median household income, the interaction of the household size and income, and this interaction squared. Demographic variables thought to proxy for unobserved preferences or costs of filing, such as age, sex, marital status, education, language spoken at home, stability of residence, home ownership rates, birthplace, and race, are similarly sourced from the Census. Religious adherence rates are sourced from the ARDA. Median (owner-occupied) home values are included to proxy for differences in cost of living that affect the real cost of income tax. Finally, following Dubin, Graetz, and Wilde (1990), we include average state individual income tax rates.

We use the form:

$$
\ln \left(y_{i j, 2001} / 1-y_{i j, 2001}\right)=X_{i j, 2000}^{\prime} \beta+F_{i j, 2000}^{\prime} \delta+u_{i j, 2001},
$$

where $y_{i j, 2001}$ refers to the non-filing rate in county $i$ of state $j$ for tax year 2000 (reflecting filing behavior in 2001), $X_{i j, 2000}$ is a vector of county-level IRS-sourced rational compliance variables, demographic characteristics, and state dummies, $F_{i j, 2000}$ is the vector of $F_{\text {Income }}, F_{\text {Language }}, F_{\text {Race }}$, and $F_{\text {Religion }}$ for county $i$ in state $j$ in 2000 , and $u_{i j, 2001}$ is a random error.

\section{Endogeneity Considerations and Instruments}

As suggested by our theory, we recognize the possibility that IRS enforcement efforts against identified non-filers, as well as audit efforts against filers, may be endogenously related to the non-filing rate in equation (3) or to third factors that could explain both. ${ }^{16}$ Although filing 
behavior in, say, calendar year 2001 cannot affect audit or enforcement activity in 2000, if the idiosyncratic error term in equation (3) is serially correlated over time, it can easily be shown that audit or enforcement measures in 2000 could be correlated with $u_{2001}$ in those equations. We address potential endogeneity using instruments sourced from the IRS. These instruments need to be correlated with audit or enforcement activity in the appropriate year, yet collectively uncorrelated with the error term.

We propose and test five instruments. The first two are based on our expectations that there will be some spatial correlation in audit rates and non-filer enforcement activities, yet at the same time that non-filing behavior will be determined by perceptions of IRS enforcement in the local county only rather than surrounding areas. To capture this, we instrument with both the audit rate and enforcement index of the "nearest neighbor" county, defined as the county whose population center (or "centroid") is closest to a given county's population center.

Next, we know that IRS decisions about enforcement against both filed returns and identified non-filers are informed by third-party income reporting. We hypothesize that, as the number of information documents and the types of income covered by those documents increase per taxpayer, so too does the chance of finding a discrepancy with reported income and so also does the complexity of the (potential) return. These will likely increase the probability that a return may be flagged for audit or that a particular non-filer meets the criteria to be selected for enforcement. We therefore use as instruments the average number of third-party information documents sent to an address in a county per filed return and the average number of types of these third-party information documents (out of 23 possible types). Given that the IRS commonly initiates audit or enforcement activity one or two years later, the relevant instruments for the audit rate or enforcement index in year 2000 are averages over the two previous years. 
Finally, given the importance to the IRS of protecting or recovering improper EITC claims, we use the percent of filed returns claiming the EITC at the county level, averaged over the two previous years, as an instrument for the audit rate. While filing behavior may be correlated with eligibility for the credit in the population, once we control for factors that proxy for eligibility, our proposed instrument should be uncorrelated with the non-filing rate. ${ }^{17}$

We use two-step efficient generalized method of moments (IV-GMM) estimation to test our cross-section model for the joint validity of our five proposed instruments. ${ }^{18} \mathrm{We}$ find that these instruments are sufficiently correlated with the audit and enforcement measures and sufficiently uncorrelated with the error term to be valid. ${ }^{19}$ Moreover, we find that exogeneity of the audit rate and enforcement index together could be rejected at the 5 percent level for every model. We therefore estimate and present results from generalized method of moments (IVGMM) estimations rather than from OLS estimations.

\section{Some Robustness Tests}

It should be noted that we have estimated many alternative specifications. We have used different measures of the non-filing rates, and these alternative results are discussed later. We have tried many different combinations of explanatory variables, including a measure of countylevel political affiliation. ${ }^{20}$ Finally, although we have included a wide range of county-level characteristics as explanatory variables, there remains a risk of omitted variable bias if there is some unobservable factor that is correlated with the error term. Because of this, and because we have available IRS data on non-filing rates for the years 2000 to 2006, we have also estimated fixed effects regressions based on these years, for the various definitions of non-filing rates, using non-IRS data for non-census years from the American Community Survey and Area Resource File. These fixed effects estimations have the advantage of controlling for unobserved 
but stable differences over time between counties. Unfortunately, from 2001 to 2006, many nonIRS variables are available only from sampling or imputation at the state or county level, and thus they may not adequately capture variation at the county level. In particular, the socioeconomic diversity measures are not all available for all of these years, so we are unable to examine fully the effects of heterogeneity in these fixed effects regressions. These fixed effects regressions are not reported, but are available upon request

\section{RESULTS}

\section{Main Results}

Results for our main measure of non-filing are provided in Table $2 .{ }^{21} \mathrm{We}$ focus for the moment on the coefficients that show consistent results in direction and significance. We discuss our various robustness tests later.

Rational compliance variables have the expected impacts on non-filing rates. The enforcement index against identified non-filers has a negative and statistically significant impact, such that counties with maximum observed enforcement have an odds of non-filing 77 percent that of counties with the minimum observed enforcement. Conversely, the audit rate for filed returns has a positive impact on non-filing, though it is not statistically significant. As suggested by the simple correlation coefficients, penalty rates for filers or for non-filers have a small and insignificant impact on non-filing rates.

Several other control variables have generally significant effects on non-filing rates. Relative to a baseline, non-filing rates are decreasing in the share married and in measures of residential stability, in the share who are over 65 or teenagers, in the share in the labor force, in several proxies for EITC eligibility, and in some race and religious adherents shares. Non-filing 
is also decreasing in several proxies for eligibility for EITC funds that first rise and then fall in household earned income and size. Non-filing rates are increasing in the share of income reported from self-employment or public assistance, in the share foreign born, in the population share who are aged 45-64, in the share with some college education but not a bachelor's degree, in real median home value, in the share in owner-occupied housing, and in some race shares. The positive association between share of income from social security or public assistance and nonfiling is of interest, given the ready ability of the IRS to trace such payments. This result might suggest that individuals receiving these funds do not understand their filing requirements, so that targeted taxpayer assistance might be helpful. The positive association between home value and share owner occupied housing and non-filing might suggest those with greater wealth and less third party reporting entanglements from landlords declaring rental income of tenants are more likely to avoid the system.

Of particular interest, some measures of heterogeneity seem consistently associated with effects on non-filing rates, while others do not. Greater racial fragmentation is associated with higher rates of non-filing. In particular, the coefficient 0.423 indicates that a move from minimum to maximum observed racial heterogeneity increases the odds of non-filing (i.e. the probability of non-filing divided by the probability of filing) by 53 percent (or $e^{0.423}=1.53$ ). (The sample mean odds of non-filing is 0.0204 .) Surprisingly, greater religious fragmentation is associated with less non-filing. A county with maximum observed religious heterogeneity would have odds of non-filing 88 percent that of a county with minimum heterogeneity (or $e^{-.123}=0.88$ ). In contrast, income inequality and language fragmentation bear no statistical relationship to the rate of non-filing.

Some Robustness Tests 
Table 3 reports alternative estimates using our broader (including later filers or those who owed no money) and narrower (owing at least \$500) definitions of non-filing rates. Using the same empirical approach as before, we find that the same instruments are valid and that endogeneity is indicated as before (see note 18).

Table 3 results show many of the same patterns as in Table 2. For example, our results for social diversity are largely the same. Non-filing is again increasing in racial heterogeneity, with a similar magnitude of effect. Similarly, there is no association between non-filing and language fragmentation or income inequality, and religious heterogeneity is negatively associated with non-filing, as before.

As for other variables, the effectiveness of IRS enforcement efforts against non-filers depends on the seriousness of the non-filing. Compared to counties with minimum enforcement, counties with maximum enforcement against non-filers have odds of non-filing that are 59 percent as high for broad non-filing, 77 percent as high for our main definition, and 80 percent as high for our narrowest definition; that is, enforcement activity against identified non-filers seems most effective in reducing the least egregious cases of non-filing (e.g., late filers), or those who legally needed to file but owed no money. Non-filing again looks to be increasing in the audit rate of filers, but the effects are not significant.

Finally, non-filing is robustly decreasing in the share married and in measures of residential stability, in the share who are over 65 (except for our narrower definition) or teenagers, in the share in the labor force, in several proxies for EITC eligibility, and in some race and religious adherents shares (e.g., Evangelical Protestant). Non-filing rates are again increasing in the share of income reported from self-employment or public assistance, in the share foreign born, in the population share who are aged 45-64, in the share with some college education but 
not a bachelor's degree, in real median home value, in the share in owner-occupied housing, and again in some race shares.

\section{Conclusions}

This paper examines the factors that affect non-filing rates in the U.S., focusing on deterrence variables and heterogeneity measures (by income, language, race, or religion). We find that non-filing rates are affected in predictable ways by enforcement efforts against identified non-filers. Counties experiencing the highest enforcement have odds of non-filing ranging from 59 percent to 80 percent of the odds of non-filing in counties experiencing the lowest enforcement. We also find that non-filing rates are rising in racial fragmentation. Counties with the highest racial fragmentation have odds of non-filing ranging from 49 percent to 53 percent higher than the odds of non-filing in counties with the lowest racial fragmentation. Among other dimensions of heterogeneity, non-filing rates do not appear affected by household income inequality or language fragmentation. More surprisingly, we also find non-filing rates fall modestly with religious membership fragmentation, with high fragmentation counties having non-filing rates 84 percent to 88 percent of non-filing rates in low fragmentation counties.

Why would people in the United States be less likely to file federal taxes when their county is more diverse by race, but not more diverse by language or income? Explanations based on different propensities to file taxes among different racial groups in the U.S., perhaps due to the country's specific history of race relations or immigration, would not be adequate, as these would be picked up by our controls for county population shares by race. Our speculation is that race remains the most obvious dimension of social diversity that people notice in the general population living and working around them, indicators than are more salient than diversity by 
language or income. Perhaps coupled with the specific history of U.S. race relations, this could explain why local racial diversity would affect federal tax filing when other factors do not.

Our estimated effects of racial fragmentation on filing compliance rates are consistent with the findings of previous studies in the social capital literature that estimate the effects of racial heterogeneity on compulsory activities such as census return rates (Vigdor 2004), or on voluntary activities such as volunteering, voting, or being a member of an organization (Alesina and La Ferrara 2000, 2002; Costa and Kahn 2003a, 2003b; Putnam 2007; Clark and Kim 2012). To the extent that these findings regarding racial fragmentation persist, it seems worthwhile to explore ways to reduce racial heterogeneity's effects on both compulsory and voluntary indicators of social capital, especially given that the U.S. and indeed all OECD countries are growing ever more racially diverse (Putnam 2007). As discussed in Li (2010), tax agencies that emphasize common benefits from a well-functioning tax system might reduce filing noncompliance. More broadly, in increasingly diverse societies, governments may wish to set policies that emphasize shared citizenship, shared identity, and common values. Of course, these diversity policies need also to be combined with enforcement measures.

\section{REFERENCES}

Alesina, Alberto, and Eliana La Ferrara. 2000. Participation in heterogeneous communities. The Quarterly Journal of Economics 115 (3): 847-904.

Alesina, Alberto, and Eliana La Ferrara. 2002. Who trusts others? Journal of Public Economics 85 (2): 207-234.

Alesina, Alberto, Arnaud Devleeschauwer, William Easterly, Sergio Kurlat, and Romain Wacziarg. 2003. Fractionalization. Journal of Economic Growth 8 (2): 155-194.

Alesina, Alberto, Reza Baqir, and William Easterly. 1999. Public goods and ethnic divisions. The Quarterly Journal of Economics 114 (4): 1243-1284.

Allingham, Michael G., and Agnar Sandmo. 1972. Income tax evasion: A theoretical analysis. Journal of Public Economics 1 (3-4): 323-338.

Alm, James. 2012. Measuring, explaining, and controlling tax evasion: Lessons from theory, experiments, and field studies. International Tax and Public Finance 19 (1): 54-77. 
Alm, James, Todd Cherry, Michael Jones, and Michael McKee. 2010. Taxpayer information assistance services and tax reporting behavior. Journal of Economic Psychology 31 (4): 577-586.

Alm, James, Gary H. McClelland, and William D. Schulze. 1999. Changing the social norm of tax compliance by voting. Kyklos 52 (2): 141-172.

Alm, James, and Jay Shimshack (2014). Environmental enforcement and compliance: Lessons from pollution, safety, and tax settings. Foundations and Trends in Microeconomics 10 (4): 209-274.

Andreoni, James, Brian Erard, and Jonathan Feinstein. 1998. Tax compliance. The Journal of Economic Literature 36 (2): 818-860.

Baum, Christopher F. 2008. Stata tip 63: Modeling proportions. The Stata Journal 8 (2): 299303.

Becker, Gary S. 1968. Crime and punishment - An economic approach. The Journal of Political Economy 76 (2): 169-217.

Clark, Jeremy, and Bonggeun Kim. 2012. The effect of neighbourhood diversity on volunteering: Evidence from New Zealand. B.E. Journal of Economic Analysis and Policy 12 (1): 1-49.

Costa, Dora L., and Matthew E. Kahn. 2003a. Understanding the American decline in social capital, 1952-1998. Kyklos 56 (1): 17-46.

Costa, Dora L., and Matthew W. Kahn. 2003b. Civic engagement and community heterogeneity: An economist's perspective. Perspectives on Politics 1 (1): 103-111.

Cowell, Frank A. 1990. Cheating the Government: The Economics of Evasion. Cambridge, MA: The MIT Press.

Cowell, Frank A., and James P. F. Gordon. 1988. Unwillingness to pay. Journal of Public Economics 36 (3): 305-321.

Dubin, Jeffrey A., Michael J. Graetz, and Louis L. Wilde. 1990. The effect of audit rates on the federal individual income tax, 1977-1986. National Tax Journal 43 (4): 395-409.

Elster, Jon. 1989. The cement of society - A study of social order. Cambridge, UK: Cambridge University Press.

Erard, Brian, and Chih-Chin Ho. 2001. Searching for ghosts: who are the non-filers and how much tax do they owe? Journal of Public Economics 81 (1): 25-50.

Fortin, Bernard, Guy Lacroix, and Marie-Clare Villeval. 2007. Tax evasion and social interactions. Journal of Public Economics 91 (8): 2089-2112.

Gentry, William M., and Matthew E. Kahn. 2009. Understanding spatial variation in tax sheltering: The role of demographics, ideology, and taxes. International Regional Science Review 32 (3): 400-423.

Gordon, James P. P. 1989. Individual morality and reputation costs as deterrents to tax evasion. European Economic Review 33 (4): 797-805.

Gneezy, Uri, and Aldo Rustichini. 2000. A fine is a price. Journal of Legal Studies 29 (1, Part 1): $1-18$.

Gustavsson, Magnus J., and Henrik Jordahl. 2008. Inequality and trust in Sweden: Some inequalities are more harmful than others. Journal of Public Economics 92 (3): 348-365.

Hayashi, Fumio. 2000. Econometrics. Princeton, NJ: Princeton University Press.

Hisnanick, John J., and Annette L. Rogers. 2007. Household income inequality measures based on the ACS Data: 2000-2005. Housing and Household Economic Statistics Division, U.S. Census Bureau. Washington, D.C.

Internal Revenue Service, 2012. http://www.irs.gov/pub/newsroom/overview_tax_gap_2006.pdf. 
Kim, Youngse. 2003. Income distribution and equilibrium multiplicity in a stigma-based model of tax evasion. Journal of Public Economics 87 (9): 1591-1616.

Kirchler, Erich, Stephan Muehlbacher, Barbara Kastlunger, and Ingrid Wahl. 2010. Why pay taxes? A review of tax compliance decisions. In Developing alternative frameworks for explaining tax compliance, edited by James Alm, Jorge Martinez-Vazquez, and Benno Torgler. London, UK: Routledge: 15-31.

Kleven, Henrik J., Martin B. Knudsen, Claus T. Kreiner, Søren Pedersen, and Emmanuel Saez. 2011. Unwilling or unable to cheat? Evidence from a randomized tax audit experiment in Denmark. Econometrica 79 (3): 651-692.

La Porta, Rafael, Florencio Lopez-de-Silanes, Andrei Shleifer, and Robert Vishny. 1999. The quality of government. The Journal of Law, Economics and Organization 15 (2): 222279.

Leigh, Andrew. 2006. Trust, inequality and ethnic heterogeneity. The Economic Record 82 (258): 268-280.

Li, Sherry Xin. 2010. Social identities, ethnic diversity, and tax morale. Public Finance Review 38 (2): 146-177.

Luttmer, Erzo F. P. 2001. Group loyalty and the taste for redistribution. The Journal of Political Economy 109 (3): 500-528.

Miguel, Edward, and Mary Kay Gugerty. 2005. Ethnic diversity, social sanctions, and public goods in Kenya. Journal of Public Economics 89 (11-12): 2325-2368.

Myles, Gareth D., and Robin A. Naylor. 1996. A model of tax evasion with group conformity and social customs. European Journal of Political Economy 12 (1): 49-66.

Phillips, Mark D. 2012. Reconsidering the deterrence paradigm of tax compliance. The IRS Research Bulletin, Proceedings of the 2011 IRS Research Conference, Recent Research on Tax Administration and Compliance, 93-98.

Plumley, Alan H. 1996. The determinants of individual income tax compliance: Estimating the impacts of tax policy, enforcement, and IRS responsiveness. Internal Revenue Service, Publication 1916 (Rev. 11-96). Washington, D.C.

Poterba, James M. 1997. Demographic structure and the political economy of public education. Journal of Policy Analysis and Management 16 (1): 48-66.

Putnam, Robert D. 2007. E pluribus unnum: Diversity and community in the twenty-first century - The 2006 Johan Skytte prize lecture. Scandinavian Political Studies 30 (2): 137-174.

Schneider, Friedrich, and Dominik H. Enste. 2013. The shadow economy: An international survey, $2^{\text {nd }}$ edition. Cambridge, UK: Cambridge University Press.

Slemrod, Joel, and Shlomo Yitzhaki. 2002. Tax avoidance, evasion, and administration. In Handbook of Public Economics, Volume 3, edited by Alan J. Auerbach and Martin Feldstein. Amsterdam, London, and New York: Elsevier, 1423-1470.

Traxler, Christian. 2010. Social norms and conditional cooperative taxpayers. European Journal of Political Economy 26 (1): 89-103.

Vigdor, Jacob. 2004. Community composition and collective action: Analyzing initial mail responses to the 2000 census. The Review of Economics and Statistics 86 (1): 303-312. 
Figure 1. County Non-filing Rates and Enforcement Policies, Tax Year 2000

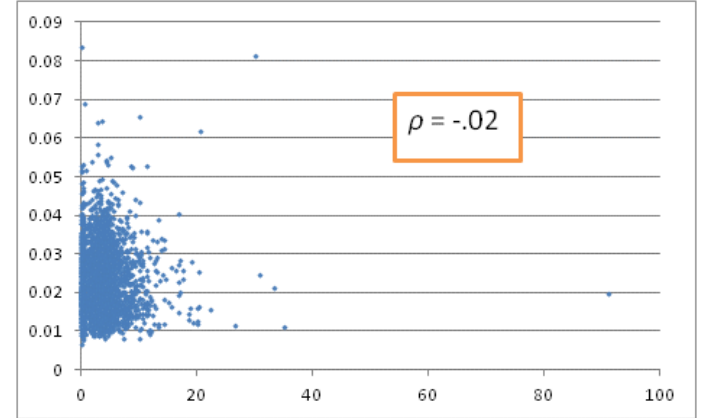

A. Non-filing Rate as a Function of Average Penalty Rate for Non-filers

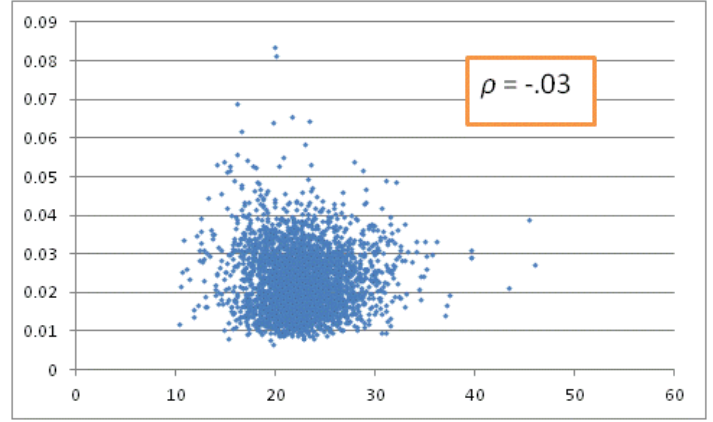

C. Non-filing Rate as a Function of Average Penalty Rate for Filers

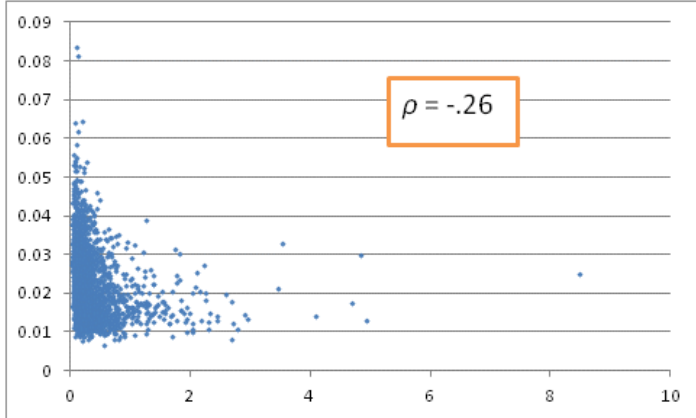

B. Non-filing Rate as a Function of Enforcement Index for Identified Non-filers

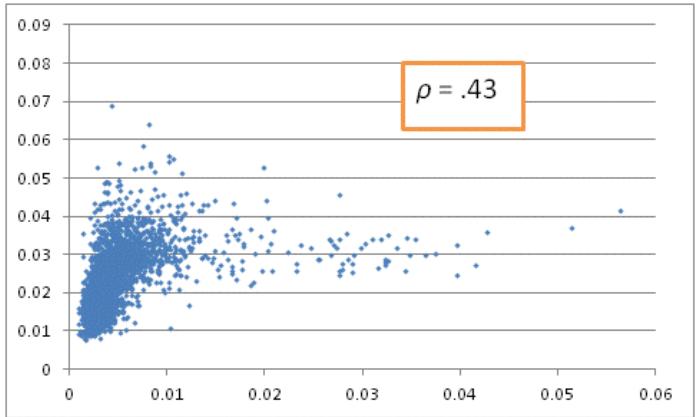

D. Non-filing Rate as a Function of Audit Rate of Filers

Figure 2. County Non-filing Rates and Social Heterogeneity, Tax Year 2000

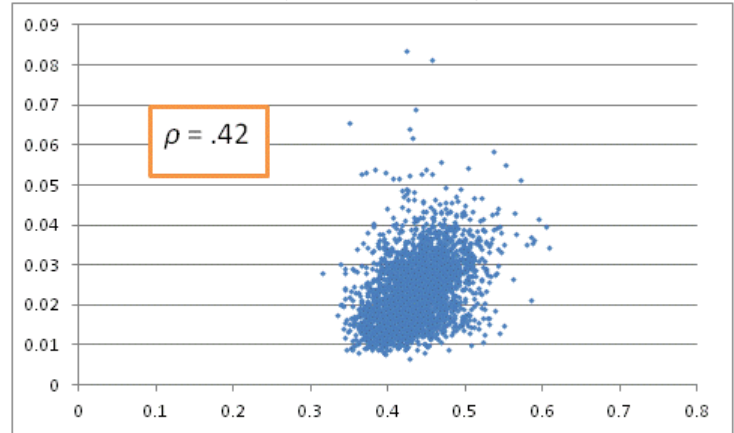

A. Non-filing Rate as a Function of Household Income Inequality (Gini)

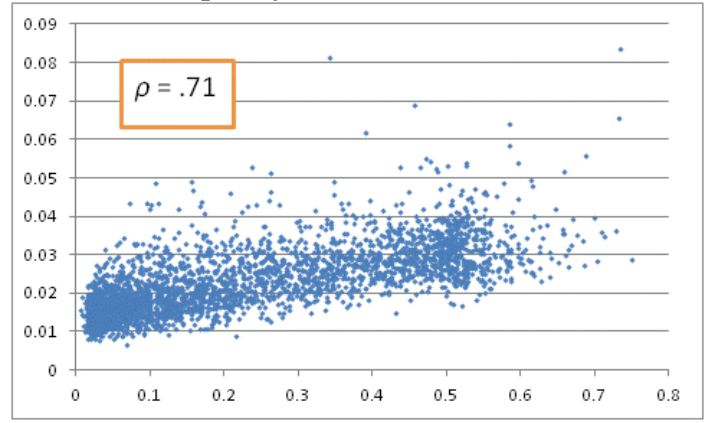

C. Non-filing Rate as a Function of Fragmentation by Race

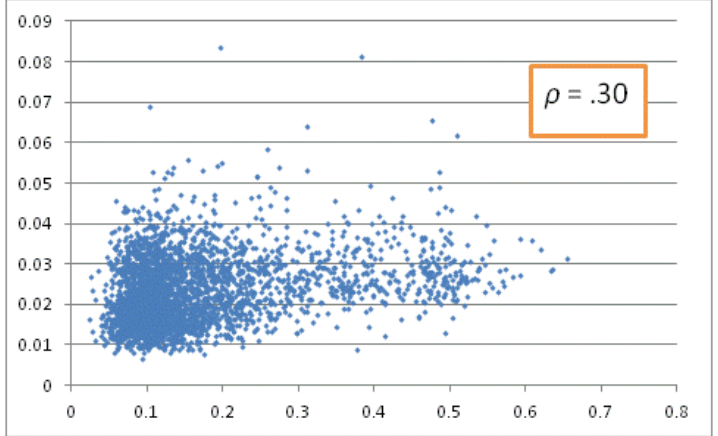

B. Non-filing Rate as a Function of Fragmentation by Home Language

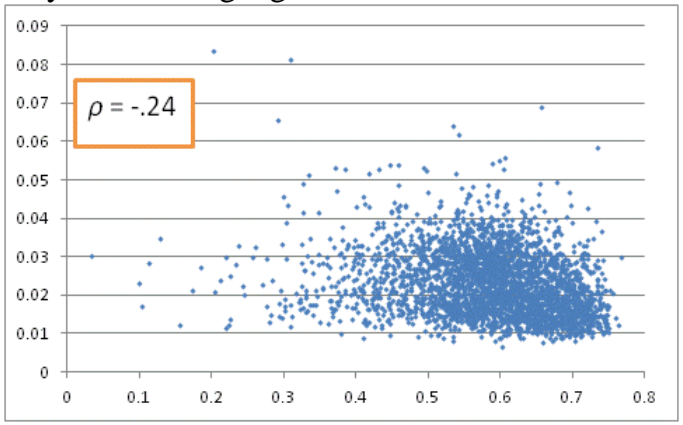

D. Non-filing Rate as a Function of Fragmentation by Religion 
Figure 3. Non-Filing Rates for Tax Year 2000, by County

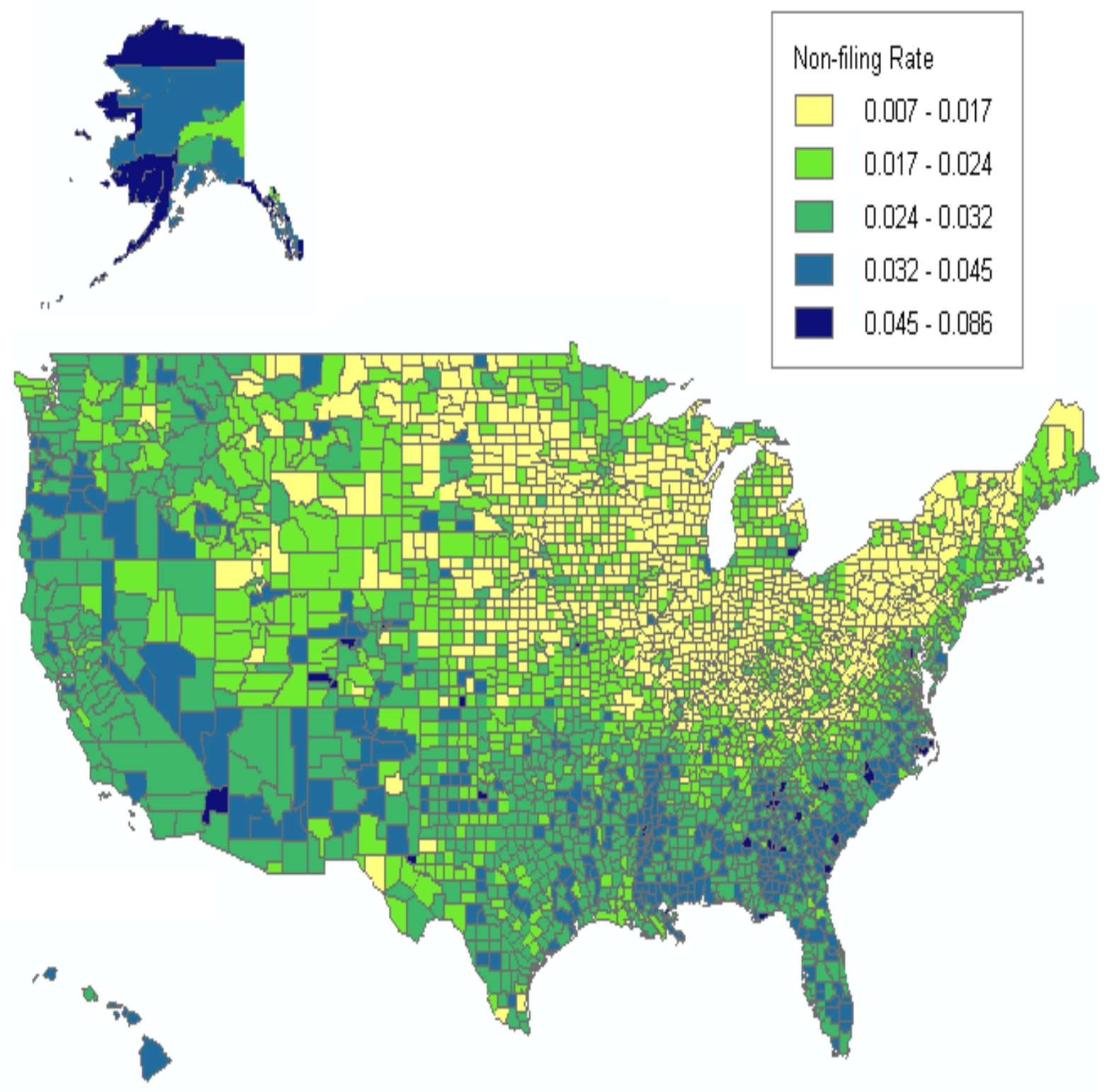


Figure 4. Measures of Social Heterogeneity for Tax Year 2000, by County

A. Household Income Inequality (Gini)

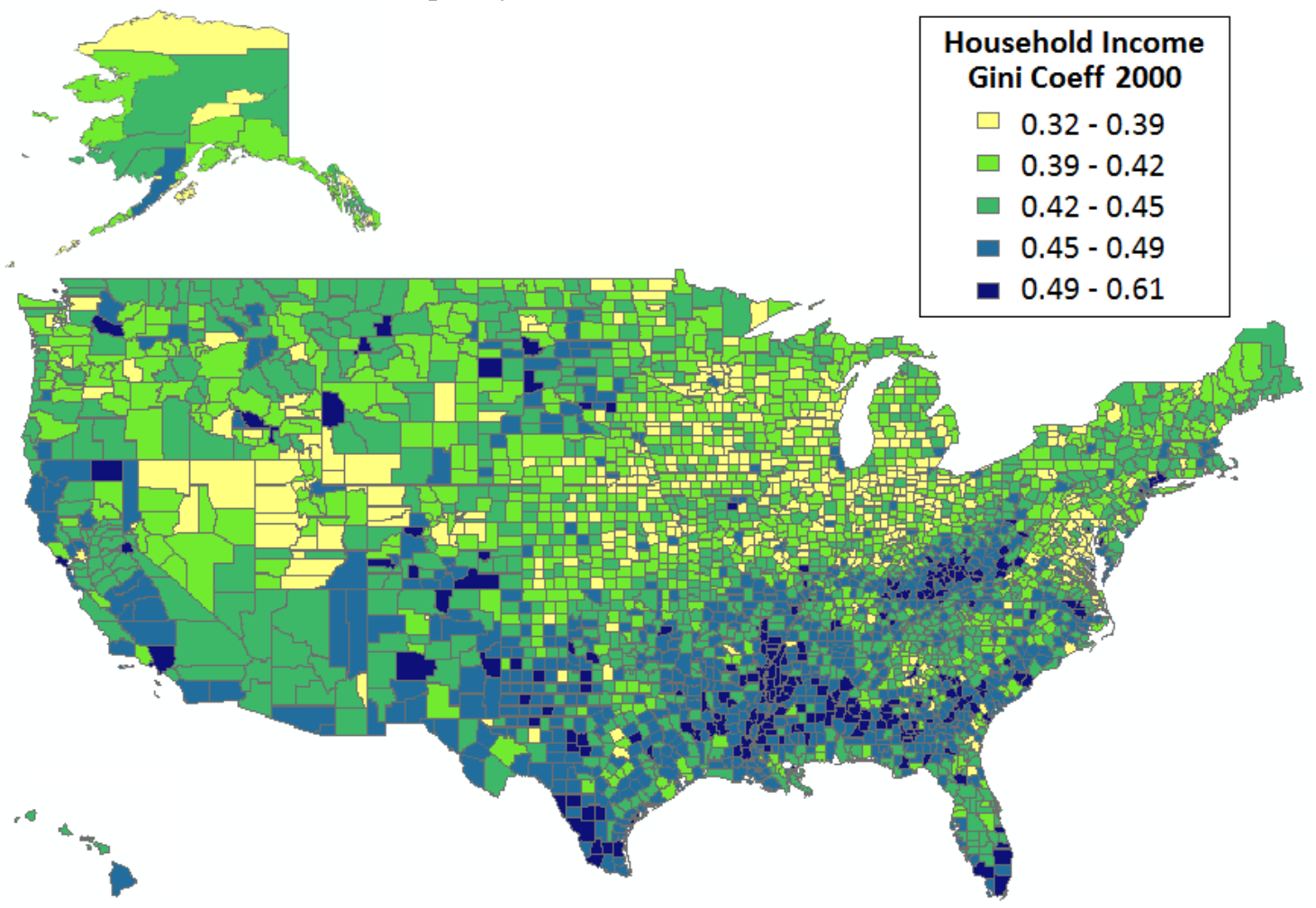

B. Home Language Fragmentation Index

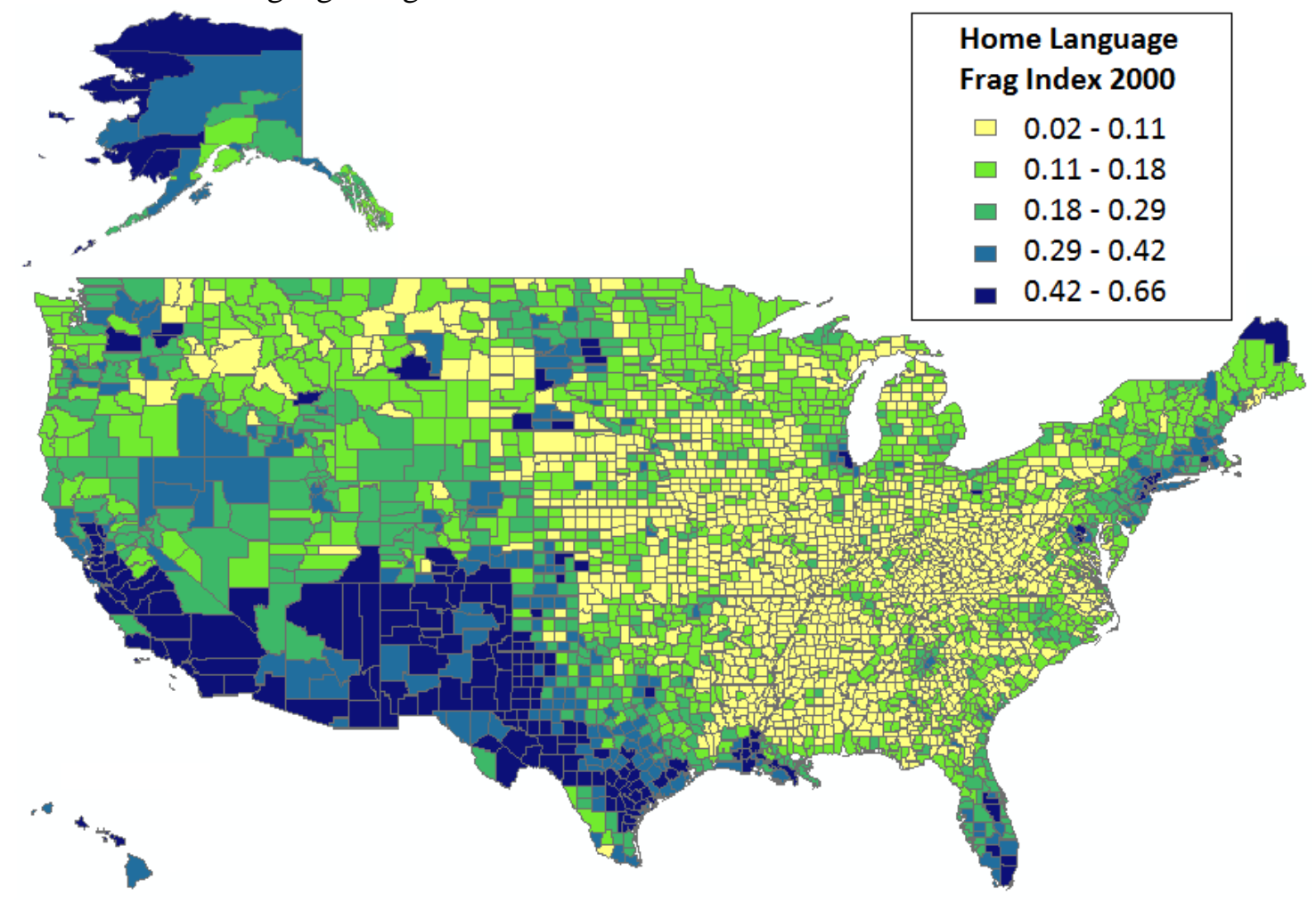


C. Race/Ethnicity Fragmentation Index

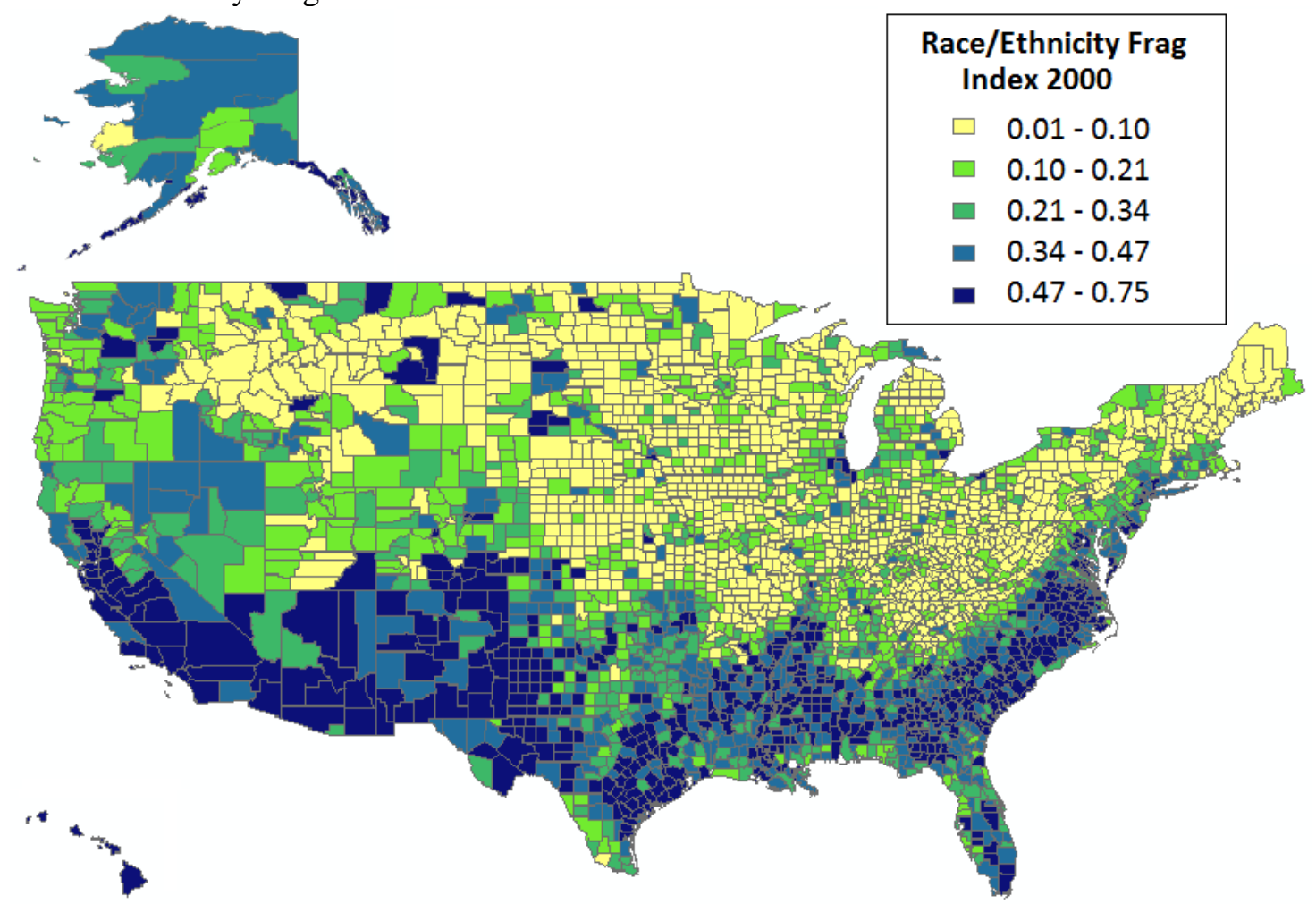

D. Religious Adherents Fragmentation Index

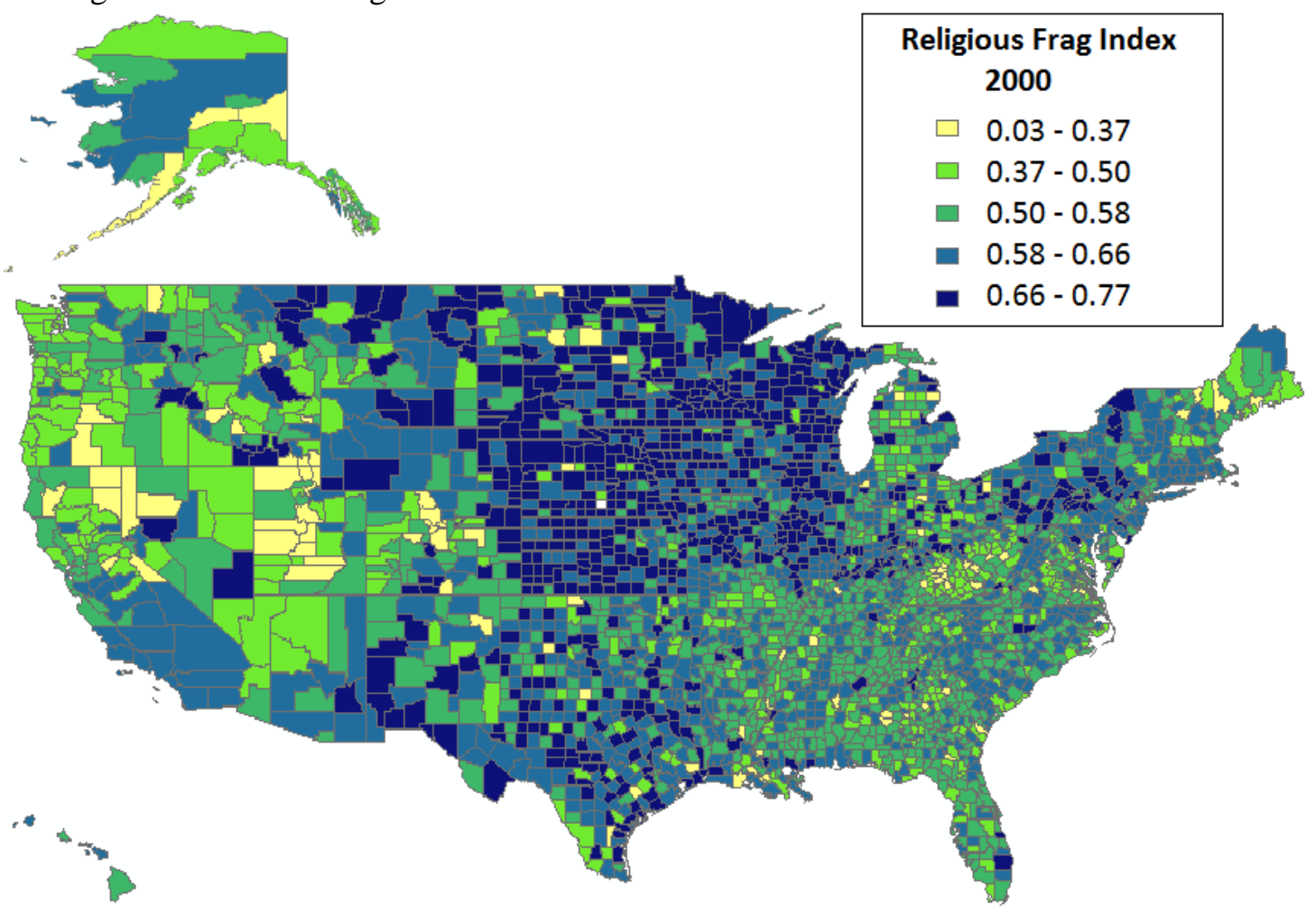


Table 1. Descriptive Statistics for Variables, Tax Year 2000

\begin{tabular}{|c|c|c|c|c|c|}
\hline Variable & $\mathbf{N}$ & Mean & St Dev & Min & $\operatorname{Max}$ \\
\hline Broad Non-filing Rate & 3027 & 0.039 & 0.015 & 0.012 & 0.194 \\
\hline Narrow Non-filing Rate $>\$ 0$ & 3027 & 0.023 & 0.009 & 0.007 & 0.083 \\
\hline Narrow Non-filing Rate $>\$ 500$ & 3022 & 0.013 & 0.006 & 0.003 & 0.057 \\
\hline Enforcement Index Broad & 2928 & 0.186 & 0.268 & 0.019 & 5.262 \\
\hline Enforcement Index Narrow $>\$ 0$ & 2926 & 0.314 & 0.441 & 0.031 & 8.500 \\
\hline Enforcement Index Narrow $>\$ 500$ & 2912 & 0.611 & 0.872 & 0.053 & 14.730 \\
\hline Audit Rate Filers & 2638 & 0.005 & 0.005 & 0.001 & 0.056 \\
\hline Penalty Rate Non-filers & 3133 & 3.491 & 3.812 & 0.000 & 91.280 \\
\hline Penalty Rate Filers & 3141 & 22.670 & 3.989 & 10.290 & 55.380 \\
\hline Nearest Neighboring (NN) Enforcement Index Broad & 2915 & 0.182 & 0.286 & 0.019 & 5.262 \\
\hline NN Enforcement Index Narrow >\$0 & 2912 & 0.305 & 0.462 & 0.031 & 8.500 \\
\hline NN Enforcement Index Narrow $>\$ 500$ & 2898 & 0.596 & 0.918 & 0.061 & 14.730 \\
\hline NN Audit Rate Filers & 2639 & 0.005 & 0.004 & 0.001 & 0.056 \\
\hline Information Documents Per Filed Return & 3141 & 8.660 & 7.125 & 2.636 & 170.60 \\
\hline Information Documents Types / 23 & 3141 & 0.756 & 0.196 & 0.000 & 1.000 \\
\hline Percent Returns Seeking EITC & 3138 & 0.183 & 0.083 & 0.028 & 0.584 \\
\hline Share Male & 3140 & 0.496 & 0.022 & 0.000 & 0.676 \\
\hline Real Median Household Income/10,000 & 3138 & 3.637 & 0.901 & 1.523 & 9.121 \\
\hline Education $<$ High School & 3140 & 0.226 & 0.088 & 0.030 & 0.653 \\
\hline Education High School Diploma & 3140 & 0.347 & 0.066 & 0.109 & 0.533 \\
\hline Education Some College/Associate Degree & 3140 & 0.262 & 0.057 & 0.095 & 0.449 \\
\hline Education Bachelor's Degree & 3140 & 0.110 & 0.049 & 0.000 & 0.400 \\
\hline Education Masters/PhD/Professional Degree & 3140 & 0.056 & 0.033 & 0.000 & 0.360 \\
\hline Share Age $<15$ & 3139 & 0.206 & 0.028 & 0.021 & 0.381 \\
\hline Share Age 15-19 & 3139 & 0.075 & 0.013 & 0.000 & 0.244 \\
\hline Share Age 20-24 & 3139 & 0.060 & 0.025 & 0.014 & 0.292 \\
\hline Share Age 25-44 & 3139 & 0.275 & 0.032 & 0.145 & 0.481 \\
\hline Share Age 45-64 & 3139 & 0.236 & 0.028 & 0.054 & 0.459 \\
\hline Share Age 65 Plus & 3139 & 0.147 & 0.042 & 0.018 & 0.347 \\
\hline \multicolumn{6}{|l|}{ Share of Household Income from: } \\
\hline Wages and Salaries & 3140 & 0.686 & 0.074 & 0.384 & 0.881 \\
\hline Self-employment & 3140 & 0.076 & 0.037 & 0.000 & 0.390 \\
\hline Interest/Dividends/Net Rental & 3140 & 0.067 & 0.027 & 0.005 & 0.241 \\
\hline Social Security & 3140 & 0.077 & 0.025 & 0.005 & 0.188 \\
\hline Supplemental Social Security & 3140 & 0.007 & 0.005 & 0.000 & 0.060 \\
\hline Public Assistance & 3140 & 0.002 & 0.002 & 0.000 & 0.064 \\
\hline Retirement Funds & 3140 & 0.061 & 0.024 & 0.003 & 0.252 \\
\hline Other Income & 3140 & 0.024 & 0.007 & 0.000 & 0.078 \\
\hline Never Married & 3140 & 0.225 & 0.056 & 0.090 & 0.561 \\
\hline Currently Married (not Separated) & 3140 & 0.585 & 0.059 & 0.197 & 0.876 \\
\hline Widowed/Divorced/Separated & 3140 & 0.190 & 0.030 & 0.034 & 0.605 \\
\hline
\end{tabular}

\begin{tabular}{|l|rrrrr|}
\hline Variable & N & Mean & St Dev & Min & Max \\
\hline Share English at Home & 3140 & 0.894 & 0.115 & 0.044 & 0.988 \\
Share Spanish at Home & 3140 & 0.062 & 0.104 & 0.000 & 0.950 \\
Share Other Language at Home & 3140 & 0.044 & 0.055 & 0.000 & 0.719 \\
Median Years at Residence & 3140 & 7.249 & 2.195 & 2.000 & 18.000 \\
Share Foreign Born & 3140 & 0.035 & 0.049 & 0.000 & 0.509 \\
Median Home Value/10,000 & 3140 & 8.458 & 4.773 & 0.000 & 100.00 \\
Share White Non-Hispanic & 3139 & 0.822 & 0.191 & 0.021 & 0.997 \\
Share White Hispanic & 3139 & 0.059 & 0.118 & 0.000 & 0.969 \\
Share Black Non-Hispanic & 3139 & 0.088 & 0.145 & 0.000 & 0.860 \\
Share Black Hispanic & 3139 & 0.002 & 0.003 & 0.000 & 0.110 \\
Share American Indian/Alaskan Native & 3139 & 0.020 & 0.078 & 0.000 & 0.950 \\
Share Asian & 3139 & 0.009 & 0.025 & 0.000 & 0.586 \\
Share Hawaiian/Pacific Islander & 3139 & 0.001 & 0.009 & 0.000 & 0.435 \\
Share Mainline Protestant & 3139 & 0.141 & 0.113 & 0.000 & 0.819 \\
Share Evangelical Protestant & 3139 & 0.227 & 0.168 & 0.000 & 0.983 \\
Share Catholic & 3139 & 0.136 & 0.147 & 0.000 & 0.900 \\
Share Orthodox & 3139 & 0.001 & 0.006 & 0.000 & 0.191 \\
Share Other Religions & 3139 & 0.023 & 0.085 & 0.000 & 0.916 \\
Share Unclaimed Adherents & 3139 & 0.471 & 0.181 & 0.000 & 0.982 \\
Home Ownership Rate & 3140 & 0.739 & 0.078 & 0.000 & 0.895 \\
Average Household Size & 3140 & 2.538 & 0.204 & 1.280 & 4.380 \\
Unemployment Rate & 3140 & 0.048 & 0.026 & 0.000 & 0.276 \\
Share Civilian Population in Labor Force & 3139 & 0.736 & 0.112 & 0.000 & 1.563 \\
Share Poverty (x 100) & 3139 & 13.290 & 5.595 & 0.000 & 42.200 \\
Heterogeneity - Fragmentation by: & & & & & \\
Household Income (Gini) & 3140 & 0.434 & 0.039 & 0.315 & 0.609 \\
Language Spoken at Home & 3140 & 0.168 & 0.114 & 0.024 & 0.655 \\
Race & 3139 & 0.234 & 0.186 & 0.005 & 0.749 \\
Religion & 3139 & 0.585 & 0.099 & 0.033 & 0.768 \\
\hline & & & & &
\end{tabular}


Table 2. Estimation of Non-filing Rate, IV-GMM

\begin{tabular}{|c|c|c|}
\hline & Coefficient & (Standard Error) \\
\hline \multicolumn{3}{|l|}{ Heterogeneity: } \\
\hline Household Income & .163 & $(.231)$ \\
\hline Language & .165 & $(.134)$ \\
\hline Race & $.423^{* * *}$ & $(.072)$ \\
\hline Religion & $-.123^{*}$ & $(.065)$ \\
\hline Enforcement Index Non-filers & $-.267^{* * *}$ & $(.101)$ \\
\hline Penalty Rate Non-filers & .001 & $(.001)$ \\
\hline Audit Rate Filers & 1.68 & $(1.73)$ \\
\hline Penalty Rate Filers & -.002 & $(.002)$ \\
\hline \multicolumn{3}{|l|}{ Share Race: } \\
\hline White Hispanic & -.238 & $(.395)$ \\
\hline Black Non-Hispanic & $.182^{*}$ & $(.106)$ \\
\hline Black Hispanic & $-3.21^{* *}$ & (1.41) \\
\hline American Indian/Alaskan Native & $.512^{* * * *}$ & $(.151)$ \\
\hline Asian & -.503 & $(.323)$ \\
\hline Hawaiian/Pacific Islander & $5.31^{*}$ & $(3.04)$ \\
\hline Share Foreign Born & $.723^{* * *}$ & $(.237)$ \\
\hline Speak Spanish at Home & .199 & $(.428)$ \\
\hline Speak Other Language at Home & $-.363^{*}$ & $(.186)$ \\
\hline \multicolumn{3}{|l|}{ Share Religious Adherents: } \\
\hline Mainline Protestant & -.017 & $(.092)$ \\
\hline Evangelical Protestant & $-.090^{* *}$ & $(.023)$ \\
\hline Catholic & -.089 & $(.059)$ \\
\hline Orthodox & 1.24 & $(1.15)$ \\
\hline Other Religion & -.076 & $(.091)$ \\
\hline Average Household Size & $-.798^{* * *}$ & $(.200)$ \\
\hline Real Median Household Income & $-.383^{* * *}$ & $(.087)$ \\
\hline Real Household Income X Average Household Size & $.267^{* * *}$ & $(.047)$ \\
\hline$($ Real Household Income X Average Household Size)^2 & $-.004^{* * *}$ & $(.001)$ \\
\hline Share Male & .312 & $(.392)$ \\
\hline Share Married & $-1.63^{* * *}$ & $(.328)$ \\
\hline Share Widow/Divorced/Separated & .613 & $(.590)$ \\
\hline \multicolumn{3}{|l|}{ Age Shares: } \\
\hline $15-19$ & $-3.35^{* * *}$ & $(1.07)$ \\
\hline $20-24$ & -1.06 & $(.657)$ \\
\hline $25-44$ & -.907 & $(.594)$ \\
\hline $45-64$ & $1.43^{* * * *}$ & $(.473)$ \\
\hline 65 Plus & $-1.33^{* *}$ & $(.535)$ \\
\hline Share in Civilian Labor Force & $-.223^{* * *}$ & $(.060)$ \\
\hline Unemployment Rate & -.216 & $(.245)$ \\
\hline Share Poverty & $.018^{* * * *}$ & $(.004)$ \\
\hline \multicolumn{3}{|l|}{ Share Education: } \\
\hline$<$ High School & .099 & $(.171)$ \\
\hline Some College & $.524^{* * * *}$ & $(.182)$ \\
\hline Bachelors & .033 & $(.235)$ \\
\hline Masters/PhD & .402 & $(.253)$ \\
\hline \multicolumn{3}{|l|}{ Share Income: } \\
\hline Self-employment & $1.46^{* * * *}$ & $(.267)$ \\
\hline Interest/Dividends/Net Rental & -.089 & $(.274)$ \\
\hline Social Security & $1.47^{* *}$ & $(.690)$ \\
\hline Supplemental Social Security & -3.08 & $(2.36)$ \\
\hline Public Assistance & $15.5^{* * * *}$ & $(.190)$ \\
\hline Retirement Funds & .021 & $(.272)$ \\
\hline Other Sources & 1.43 & $(.978)$ \\
\hline Median Years Residence & $-.023^{* * *}$ & $(.004)$ \\
\hline Real Median Home Value & $.006^{* * *}$ & $(.002)$ \\
\hline Share Household Owner Occupied & $.314^{* *}$ & $(.128)$ \\
\hline Intercept & $-1.85^{* *}$ & $(.780)$ \\
\hline Centered $\mathrm{R}^{2}$ & \multicolumn{2}{|c|}{827} \\
\hline $\mathrm{N}$ & \multicolumn{2}{|c|}{2275} \\
\hline
\end{tabular}

Notes: The model is estimated using Stata 12.0 (ivreg2). The numbers in parentheses are robust standard errors. *, $* *$, and $* * *$ refer to two-tailed significance at the 10,5, and 1 percent levels, respectively. Enforcement Index Nonfilers and Audit Rate Filers are instrumented. 
Table 3. Estimation of Broader and Narrower Non-filing Rate, IV-GMM

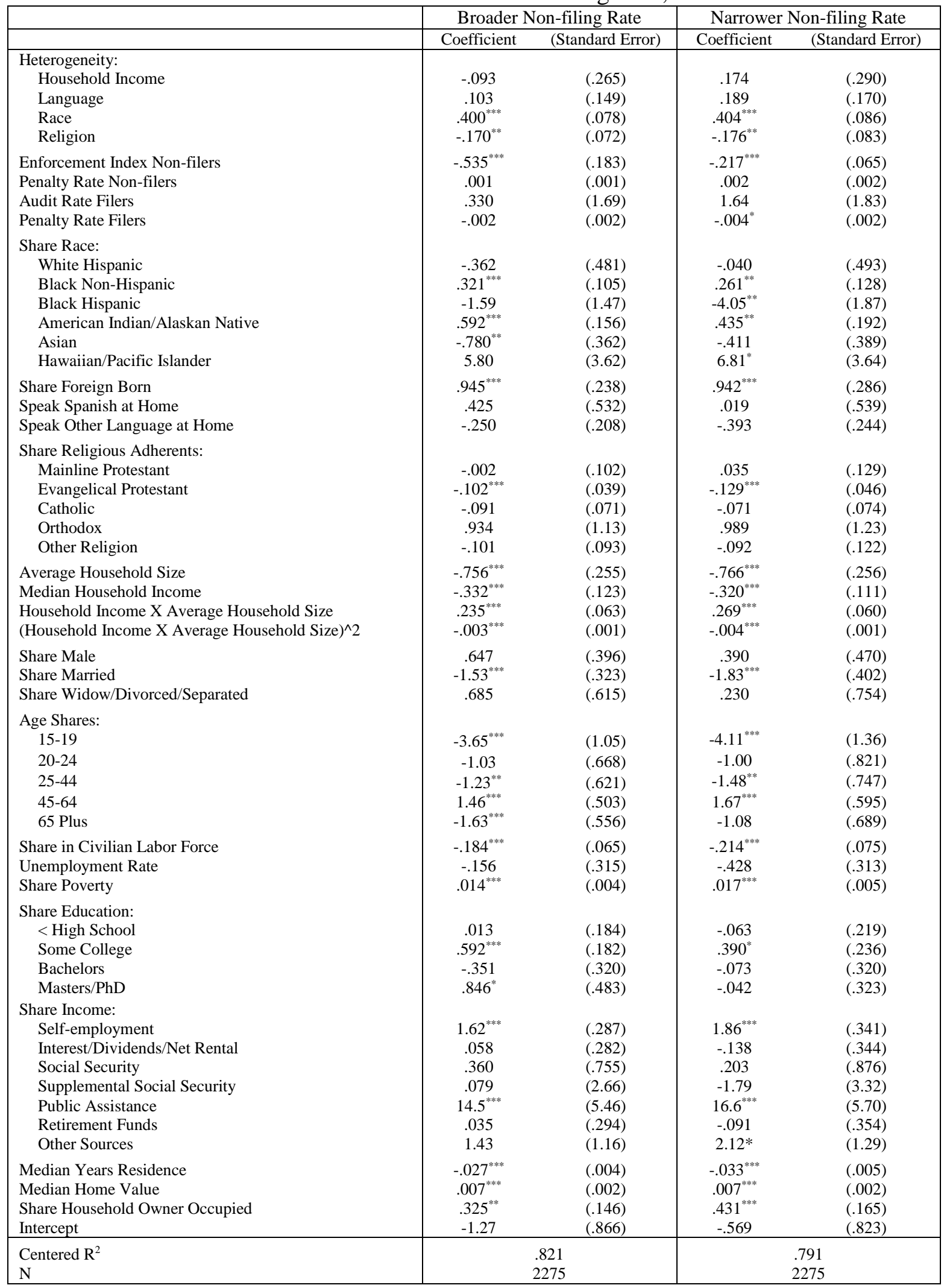

Notes: The models are estimated using Stata 12.0 (ivreg2). The numbers in parentheses are robust standard errors. *, $* *$, and *** refer to two-tailed significance at the 10, 5, and 1 percent levels, respectively. Enforcement Index Nonfilers and Audit Rate Filers are instrumented. 


\section{Notes}

${ }^{1}$ See Schneider and Enste (2000, 2002) for detailed discussions and critiques of these approaches, in the context of the "shadow economy". For more a recent discussion, see Slemrod and Weber (2012).

${ }^{2}$ The observation that observed compliance is generally high while expected penalties appear low is not limited to tax compliance. See Alm and Shimshack (2014) for a discussion of this evidence for compliance with environmental and occupational safety regulations.

${ }^{3}$ Of course, measuring "social capital" poses difficulties. As we discuss in some detail later, we use socio-economic diversity as our indicator. Other measures are possible. For example, some studies use indicators of individual behavior, such as the propensity to volunteer, vote, join organizations, contribute to fundraisers, trust others, or support welfare programs (Alesina and La Ferrara 2000, 2002; Luttmer 2001; Costa and Kahn 2003a, 2003b; Miguel and Gugerty 2005; Leigh 2006; Putnam 2007; Gustavsson and Jordahl 2008; Clark and Kim 2012).

${ }^{4}$ A notable exception is work by Erard and Ho (2001), who use data from the IRS Taxpayer Compliance Measurement Program (TCMP) to estimate the filing decision and to compare characteristics of located non-filers with filers. Also, Dubin, Graetz, and Wilde (1990), examine the effects of IRS audit rates on both reporting and filing compliance using audit data from the Annual Report of the Commissioner of Internal Revenue; similarly, Plumley (1996) estimates factors that affect both reporting and filing compliance using IRS data aggregated to the state level for the period 1982-1991. All of these studies find that audit rates affect filing compliance. They also find some evidence that filing rates are affected by self-employment, occupation, education, age, unemployment, and state-level tax burden. However, none of these studies examines the effect of heterogeneity on filing rates.

${ }^{5}$ The IRS defines individual income tax non-filers as individuals who were legally required to file an income tax return and for whom a return had not been filed by the due date or extended due date. The non-filers we use to construct our tax filing compliance rates are only those identified by the IRS and are therefore a subset of the full set of non-filers in the population.

${ }^{6}$ See Cowell (1990), Andreoni, Erard, and Feinstein (1998), Slemrod and Yitzhaki (2002), and Alm (2012) for comprehensive surveys and discussions of this literature.

${ }^{7}$ See Phillips (2012) for a recent discussion of the relationship between the probability of detection and the amount of reported income.

${ }^{8}$ There is also an extensive literature on social interactions theory as applied to tax evasion; see Cowell and Gordon (1988), Gordon (1989), Myles and Naylor (1996), Kim (2003), Fortin, Lacroix, and Villeval (2007), and Traxler (2010).

${ }^{9}$ This psychic cost is of course a simplification, and it does not fully capture such factors as stigma or guilt. We are grateful to an anonymous referee for helping clarify this consideration.

${ }^{10}$ All IRS-generated variables are censored for counties with fewer than 10 observations. For the 3140 counties in year 2000, filing rates are available for 96 percent of the counties, non-filing enforcement indices for 93 percent, audit rates for 84 percent, and both types of penalty rates for 100 percent. The counties absent from our analysis due to censoring are generally those sparsest in population, but may also reflect some that are most tax compliant.

${ }^{11}$ The limitations of our automated measure both under- and over-count the incidence of non-filing. Undercounting will occur because total taxes owed by dual earner married couples with dependents filing separately will be underestimated, as excludable income and claims for dependents will be double counted. Undercounting will also occur because taxable income not reported by third parties will not be counted, making e.g. the self-employed who self-report income un-confirmed by third parties appear over-compliant. Conversely, over-counting will occur because total taxes owed will not take account of the child tax credit or EITC, even in prior filing suggests eligibility for these credits. Similarly, if prior year tax returns are not available, the least favorable status is assumed - single, no dependents.

${ }^{12}$ IRS enforcement for identified non-filers is typically conducted through correspondence with the taxpayer. After identifying the non-filers, the IRS sends notices requesting them to file. If an individual complies with the notice and files a return, the IRS will make an assessment of unpaid taxes (and most likely penalties and interest) when the return is processed. For those who do not voluntarily comply, the 
IRS may prepare and file a "Substitute For Return" (SFR) on the individual's behalf, at which point unpaid taxes, penalties, and interest will be assessed.

${ }^{13}$ Fragmentation can be thought of as 1 minus the Herfindahl Index of concentration.

${ }^{14}$ ARDA primarily reports adherents enumerated by churches and religious organizations themselves, where adherents are defined to include full members, their children, and others who regularly attend services. Thus "Unclaimed" includes those with no religious affiliation and also those who affiliate with a religious faith but do not attend services.

${ }^{15}$ We tried grouping racial population shares and fragmentation measures to five categories (NonHispanic Whites, Hispanics, Non-Hispanic Blacks, American Indian/Alaskan Native/Hawaiian, Asians) and to three (Non-Hispanic Whites, Non-Hispanic Blacks, Other). We tried grouping religious adherents shares and fragmentation measures to four (Protestant, Catholic/Orthodox, Other Religion, Unclaimed). In no case did these changes in category definitions substantively change our results regarding the estimated effects of fragmentation or other explanatory variables on non-filing, with the obvious exception of the aggregated race or religious shares themselves.

${ }^{16}$ Although we think it less plausible, we also consider the possibility that the effective penalty rates assessed against filers and non-filers, averaged to county level, are endogenously related to non-filing rates. Because IRS penalties and interest are governed by service-wide rules, and exceptions are made on a case-by-case basis, there is less reason to think that these effective penalty rates will rise and fall with the overall filing behavior in a county. Nonetheless, we jointly test whether the two penalty rates are exogenous where the number of instruments permits. We cannot reject exogeneity, with p values all above 0.5 . One caveat to this is that, when all four enforcement variables are allowed to be potentially endogenous, the instruments themselves appear too weak collectively to be valid. Still, we think it is reasonable to treat the penalty rates as exogenous in our empirical work.

${ }^{17}$ As pointed out by a referee, this lagged EITC claim rate is defined only over actual filers, and may be a weak instrument because of its correlation with our proxies for EITC eligibility. We thus repeat our analysis for our main non-filer specification without this fifth instrument. The remaining four instruments are similarly valid, evidence for endogeneity is similar, and results in subsequent estimation are very similar to what we report here.

${ }^{18}$ The two step efficient generalized method of moments estimator (GMM) is equivalent to two stage least squares (2SLS) when a model is exactly identified, and there is conditional homoscedasticity and errors are independent and identically distributed (i.i.d). GMM gains efficiency over 2SLS when the i.i.d. assumption is relaxed and an optimal weighting matrix is used, and the model is over-identified (Hayashi 2000).

${ }^{19}$ For our main and two alternative definitions of non-filing, this involved testing whether each instrument was individually significant in at least one of the two first stage regressions, whether all five instruments together were sufficiently correlated with the audit rate and enforcement index to reject under-identification or weak identification, and whether all five were collectively uncorrelated with the error term, or over-identified. For all three models, we find that each instrument is significant at the 5 percent level or better in at least one of the two first stage regressions, and under-identification could be rejected at the 1 percent level or better using the Kleibergen-Paap rank LM statistic. Weak identification posed a moderate problem even with 5 instruments, however. In particular, Kleibergen-Paap rank F statistics could reject only a 20 percent maximum IV relative bias for all three models, with $\mathrm{F}$ statistics of 5.93, 6.28, and 6.62. Over-identification could not be rejected at the 10 percent level for all three models using the Hansen J statistic, with $\chi 2(3) \mathrm{p}$ values of $0.50,0.42$, and 0.58 . Thus our instruments are not correlated with the error term, but have some weakness. Across the main, broader, and narrower definitions of non-filing, joint exogeneity of audit and enforcement was rejected at the $0.023,0.001$, and 0.000 levels, respectively.

${ }^{20}$ We used voting data from Dave Leip's Atlas of U.S. Presidential Elections (http://uselectionatlas.org/) to construct a political affiliation variable for each county, measured as the percentage of votes for the Republican (versus the Democratic) presidential candidate at the county level in the 2000 presidential election. Political affiliation may well reflect people's attitudes towards non-filing behaviour, but it also seems likely to be correlated with many of our demographic variables. As a result, we estimated 
specifications with and without this variable. We are indebted to an anonymous referee for this suggestion.

${ }^{21}$ We report only "full" specifications that include heterogeneity measures and rational compliance variables. Recall that we estimated many alternative specifications as robustness tests, covering different measures of non-filing, different combinations of explanatory variables (including political affiliation), and fixed effects estimations. These robustness tests are discussed later. Overall, results concerning heterogeneity and rational compliance variables were very similar across the different approaches. The largest variation came from including political affiliation via percent voting Republican. Political affiliation had a negative and significant effect on non-filing. Also, with inclusion of political affiliation the effects of race heterogeneity and non-filer enforcement index were unchanged, but language heterogeneity became positive and statistically significant at the 5 percent level. Note that we also tried specifications without heterogeneity measures, and even sparser specifications that included only those non-IRS variables available at the county level for both 2000 cross section and fixed effects estimations. All results are available upon request. 